\title{
EDUKASI PENCEGAHAN PENYAKIT PARU PADA ANAK JALANAN DAN MARJINAL KOMUNITAS SAHABAT ANAK GROGOL JAKARTA BARAT
}

\author{
Octavia Dwi Wahyuni ${ }^{1}$, Hadisono ${ }^{2}$, dan Twidy Tarcisia ${ }^{3}$ \\ ${ }^{1}$ Program Studi Sarjana Kedokteran, Universitas Tarumanagara, Jakarta \\ Email: octaviaw@fk.untar.ac.id, \\ ${ }^{2}$ Program Studi Sarjana Kedokteran, Universitas Tarumanagara, Jakarta \\ Email: dokterhadisono@gmail.com \\ ${ }^{3}$ Program Studi Sarjana Kedokteran, Universitas Tarumanagara, Jakarta \\ Email: twidyt@fk.untar.ac.id
}

\begin{abstract}
Lung and respiratory disease are a condition that generates the largest burden of disability-adjusted life-years (DALYs) and most common in the world. The top estimated 10 causes of death worldwide are in 2040, three of them are due to lower respiratory tract infections, chronic obstructive pulmonary disease and lung cancer, which are members of "The Big Five". Common risk factors for respiratory disease are active and passive smoking, pollutants, densely populated areas with low socioeconomic conditions. So, the most vulnerable to exposure are street and marginalized children. In Sahabat Anak Community, which serves street and marginalized children, many children who suffer from acute respiratory infection or cough and colds that aren't getting better, some even have tuberculosis and shortness of breath. That is because they don't understand and care about the situation. Therefore, the easiest solution is providing health education and examples directly to prevent disease transmission. Participants were 100 children who assisted by Sahabat Anak Grogol, aged 4-19 years, but only 77 children from grade 4 elementary school filled the questionnaire. The results of the pre-test and post-test to determine the level of knowledge and understanding obtained an average increase from $28.57 \%$ to $71.43 \%$. Pollutants on the road (vehicle fumes, dust, cigarette smoke, etc.) are the main risk factors for COPD in street children. Increased understanding and knowledge can change behaviour so the incidence of non-communicable and non-communicable lung and airway diseases in Sahabat Anak Community can reduced and ultimately will improve their quality of life.
\end{abstract}

Keywords: education, lung and respiratory diseases, street and marginalized child, Sahabat Anak

\begin{abstract}
ABSTRAK
Penyakit paru dan saluran napas merupakan keadaan yang menghasilkan beban disability-adjusted life-years (DALYs) terbesar dan paling sering terjadi di dunia. Estimasi 10 terbanyak penyebab kematian di seluruh dunia pada tahun 2040, tiga diantaranya diakibatkan berturut-turut oleh infeksi saluran napas bawah, penyakit paru obstruksi kronik dan kanker paru yang merupakan anggota "The Big Five". Faktor risiko umum dari penyakit paru dan saluran napas tersebut yaitu perokok aktif maupun pasif, polutan, wilayah padat penduduk dengan sosioekonomi rendah sehingga yang paling rentan terpapar adalah anak jalanan dan marginal. Di Komunitas Sahabat Anak yang melayani anak-anak jalanan dan marjinal masih banyak yang menderita ISPA (infeksi saluran napas akut)/batuk pilek tidak sembuh-sembuh, beberapa bahkan TBC dan sesak napas. Hal tersebut karena mereka tidak paham dan tidak peduli mengenai keadaan tersebut. Oleh karena itu, maka solusi yang paling mudah dilakukan adalah memberikan penyuluhan dan contoh langsung cara pencegahan penularan penyakit. Peserta kegiatan adalah 100 anak binaan Sahabat Anak Grogol dengan rentang usia 4-19 tahun, tetapi pengisian kuesioner hanya dilakukan oleh 77 anak dari kelas 4 SD ke atas. Hasil pre-test dan post-test untuk mengetahui tingkat pengetahuan dan pemahaman didapatkan rerata peningkatan 28,57\% menjadi 71,43\%. Polutan di jalan (asap kendaraan, debu, asap rokok, dan lain-lain) menjadi faktor risiko utama terjadinya PPOK pada anak jalanan. Peningkatan pemahaman dan pengetahuan dapat merubah perilaku sehingga menurunkan angka kejadian penyakit paru dan saluran napas tidak menular serta tidak menular di Komunitas Sahabat Anak dan akhirnya meningkatkan kualitas hidup mereka.
\end{abstract}

Kata kunci: Edukasi, penyakit paru dan saluran napas, anak jalanan dan marginal, Sahabat Anak

\section{PENDAHULUAN}

Penyakit paru dan saluran napas merupakan keadaan atau penyakit yang paling sering terjadi di dunia. Penyakit paru dapat menimbulkan masalah tidak hanya di organ pernpasan tetapi juga menimbulkan kelainan pada sistem yang lain karena terjadi gangguan dalam pertukaran udara pernapasan (Robinson, 2018). Menurut Institute for Health Metrics and Evaluation (2018), 
estimasi 10 terbanyak penyebab kematian di seluruh dunia pada tahun 2040, 3 diantaranya diakibatkan berturut-turut oleh infeksi saluran napas bawah, penyakit paru obstruksi kronik dan kanker paru (Gambar 1). Morbiditas penyakit paru dan saluran pernapasan dapat bervariasi dari yang ringan dan dapat sembuh sendiri seperti flu sampai yang berat dan harus diobati seperti TBC, asma, pneumonia sampai kanker paru. Bayi dan anak-anak merupakan kelompok yang paling rentan menderita dan meninggal akibat penyakit ini. Bahkan, terdapat julukan "The Big Five" untuk penyakit paru dan saluran napas terbanyak dan menghasilkan beban disability-adjusted lifeyears (DALYs) terbesar di dunia yaitu COPD (chronic obstructive pulmonary disease), asma, infeksi saluran napas akut, Tuberculosis (TBC), dan kanker paru. (European Respiratory Society, 2013)

Leading causes of early death, 2016 and $2040^{+}$

\begin{tabular}{|c|c|}
\hline Leading couses in 2016 & Leading causes in 2040 \\
\hline 1 lschemic heart disesse & 1 lschemic heart disesse \\
\hline 2 Stroke & 2 Stroke \\
\hline 3 Lower respiratory infections & 3 Lower respiratory infections \\
\hline 4 Diartheal diseases & 4 COPO \\
\hline 5 Roosd injuries & 5 Chronic kidney disesse \\
\hline 6 Malaria & 6 Alzheimer's disesse \\
\hline 7 Preterm birth complications & 7 Diabetes \\
\hline 8 HIVIALS & 8 Rosd injuries \\
\hline 9 COPD & 9 tung cancer \\
\hline 10 Neonatal encepholoputhy & 10 Dianheal diseases \\
\hline 13 Lung cancer & 12 HIV/AIDS \\
\hline 15 Diabetes & 18 Preterm birth complications \\
\hline 16 Chronic kidney disease & 21 Necnatal encephalopatthy \\
\hline 18 Altheimer's disezse & 22 Malaria \\
\hline
\end{tabular}

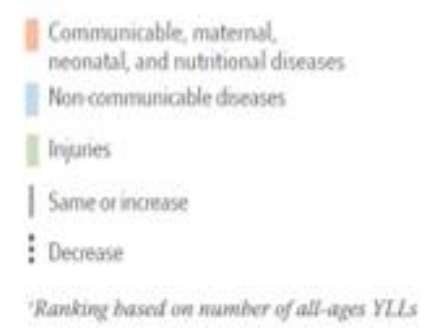

Gambar 1. Estimasi 10 Terbanyak Penyebab Kematian di Seluruh Dunia pada Tahun 2040

(IHME, 2018)

Penyebab menular penyakit paru dan saluran napas tersering berasal dari infeksi bakteri, virus, jamur dan parasite, misalnya TBC dan pneumonia. Penyebab tidak menular penyakit paru dan saluran napas tersering berasal dari rokok/asap rokok termasuk asap polusi dan bahan berbahaya lainnya serta genetik/diturunkan, misalnya COPD, asma dan kanker paru. (WHO, 2007 \& Mayo Clinic, 2017) Secara global pada tahun 2017, total penderita TBC di dunia sekitar 10 juta penderita atau sekitar 133 penderita per 100.000 penduduk. Indonesia menempati peringkat ke 3 di dunia dengan angka insiden 319 per 100.000 penduduk dan angka kematian penderita tuberkulosis 40 per 100.000 penduduk (WHO, 2018 \& Kemenkes RI, 2019a). Tahun 2018, DKI Jakarta memiliki jumlah kasus TBC sebesar 4.264 kasus untuk anak-anak di bawah 14 tahun dan angka keberhasilan pengobatan masih belum mencapai target $\geq 90 \%(81,2 \%)$. Faktor risiko terjadinya penularan TBC dan penyakit infeksi saluran napas lainnya pada anak biasanya dikarenakan tinggal di hunian yang padat penduduk dengan hygene yang buruk dan sosioekonomi rendah, pendidikan rendah,umur lebih muda, kontak lama atau tinggal serumah bersama penderita penyakit infeksi saluran napas (Yustikarini \& Sidhartani, 2015).

Salah satu penyakit paru tidak menular yang paling banyak adalah COPD dan kanker paru. COPD menempati urutan ketiga penyebab kematian global (Quaderi \& Hurst, 2018; Terzikhan, et al., 2016). Pada tahun 2016, The Global Burden of Disease Study (IHME, 2018) melaporkan jumlah 
kasus COPD secara global sebesar 251 juta kasus dengan 90\% terjadi di negara-negara perpendapatan rendah hingga sedang. Di Indonesia, prevalensi COPD sebesar 2,4\% di tahun 2018 (Kemenkes RI, 2019b). Faktor risiko utama COPD adalah perokok dan perokok pasif (WHO, 2007; Terzikhan, et al., 2016). Data Riset Kesehatan Dasar (Riskesdas) tahun 2018 menunjukkan bahwa prevalensi merokok secara nasional adalah $24,3 \%$ dengan perokok pada usia muda/ perokok pemula ( $\leq 19$ tahun) sebesar 13,4\%. Prevalensi merokok penduduk Indonesia usia 10-18 tahun pada tahun 2018 sebesar 9,2\% meningkat 1,9\% dari tahun 2013 sedangkan target RPJMN (rencana Pembangunan Jangka Menengah Nasional) 2019 sebesar 5.4\%. (Kemenkes RI, 2019a \& 2019b) Menurut WHO (2007) dan CDC (2018), banyak faktor risiko yang menyebabkan jumlah kasus COPD yang makin meningkat tiap tahun, salah satunya dikarenakan jumlah perokok yang juga meningkat tiap tahunnya. Faktor risiko yang lain adalah polusi udara dan hirupan zat berbahaya lainnya. IQAir (2019) memperlihatkan kondisi udara dan polusi Jakarta yang menempati urutan 10 besar kota di dunia dan peringkat pertama di Asia Tenggara dan di Indonesia dengan kualitas udara yang buruk. Menurut WHO (2007) paparan polutan pada usia muda akan memperbesar risiko terjadinya COPD di kemudian hari.

Dilihat dari penjelasan di atas, maka orang yang berisiko terkena penyakit paru dan saluran napas baik menular maupun tidak menular adalah usia muda, perokok aktif maupun pasif, orang yang terpapar polutan, serta orang yang tinggal di wilayah padat penduduk dengan sosioekonomi rendah. Anak jalanan dan marginal memenuhi semua faktor risiko tersebut. Salah satu organisasi yang peduli dengan anak jalanan dan marginal di Jakarta dan sekitarnya adalah Yayasan Sahabat Anak. Organisasi ini merupakan organisasi yang berbadan hukum dan menyediakan pelayanan bagi anak jalanan dan marjinal di Jakarta dan sekitarnya. (Sahabat Anak, n.d.) Salah satu bagian/anggota dari Sahabat Anak yang mempunyai anak jalanan dan kaum marginal dalam jumlah banyak adalah Sahabat Anak Grogol. Berdasarkan data dari pengurus Sahabat Anak Wilayah Grogol, Jakarta Barat, masih terdapat anak-anak dalam komunitas mereka yang sering kali menderita ISPA (infeksi saluran napas akut)/batuk pilek tidak sembuh-sembuh, beberapa bahkan ada yang menderita TBC dan sesak napas. Anak-anak komunitas Sahabat Anak Grogol tidak menyadari bahwa mereka termasuk kelompok rentan tertular dan menularkan banyak penyakit, salah satunya penyakit paru dan saluran napas. Mereka tidak paham dan tidak peduli untuk mengenali gejala-gejala penyakit paru dan saluran napas, apa yang harus diwapadai/dihindari, apa yang harus dilakukan untuk melakukan pencegahan, penghindaran penularan dan mendapatkan pengobatan jika terkena penyakit tersebut. Mereka menganggap biasa saja jika mereka atau anggota keluarga mereka sakit batuk pilek yang lama. Padahal, mereka terpapar paling banyak dengan polutan karena tinggal maupun bekerja di jalanan, baik bergaul dengan perokok maupun menjadi perokok, rentan penggunaan Napza, tinggal di kawasan padat penduduk dengan hygene dan sosioekonomi rendah. Keadaan-keadaan tersebut dan berbagai kondisi lainnya menyebabkan mereka belum terjangkau dengan baik oleh pelayanan kesehatan.

Berdasarkan kondisi tersebut, maka Fakultas Kedokteran Universitas Tarumanagara bermaksud untuk melakukan program edukasi mengenai pencegahan penyakit paru dan saluran napas di anak jalanan dan marjinal di Sahabat Anak Grogol, Jakarta Barat. Selain itu, dicotohkan secara langsung cara batuk dan bersin yang benar serta pembagian poster kesehatan ke 9 wilayah Komunitas Sahabat Anak. Program tersebut pada akhirnya ikut mendukung Rencana Strategi Kementerian Kesehatan untuk mencapai target keberhasilan pencegahan penyakit menular dan tidak menular, menurunkan jumlah pesakit dan meningkatkan kualitas hidup mereka.

\section{METODE PELAKSANAAN PKM}

Berdasarkan permasalahan dan solusi yang telah diuraikan di atas, maka kami melakukan kegiatan pengabdian masyarakat berupa edukasi kesehatan atau penyuluhan di Sahabat Anak Grogol. 
Kegiatan dilakukan dengan bantuan media visual yaitu power point dan LCD proyektor dengan topik penyuluhan yang dipilih adalah "Edukasi Pencegahan Penyakit Paru Pada Anak Jalanan Dan Marjinal Komunitas Sahabat Anak Grogol Jakarta Barat”. Materi disampaikan oleh dosen FK Untar Spesialis Paru mengenai gejala-gejala, bahaya dan pencegahan penyakit paru dan saluran napas serta merubah perilaku mereka untuk pencegahan dan penularan penyakit tersebut. Selain itu, harus diberikan contoh secara langsung bagaimana cara menutup mulut saat batuk dan bersin untuk mengurangi risiko penularan penyakit. Memori akan bertahan lebih lama jika informasi yang diberikan tidak hanya satu kali tetapi harus berulang kali. Maka, kami juga akan membagikan poster mengenai edukasi yang dilakukan saat itu kepada 8 wilayah bimbingan belajar Sahabat Anak sehingga setiap anak akan terus mengingat informasi setiap kali melihat poster tersebut. Sasaran kegiatan PKM ini adalah semua anak yang dilayani oleh Sahabat Anak Grogol dengan jumlah peserta minimal 50 anak jalanan dan marjinal berusia minimal 4 tahun.

\section{HASIL DAN PEMBAHASAN}

Kegiatan PKM dihadiri oleh 100 peserta yang terdiri dari anak jalanan dan marginal yang dibina oleh SA Grogol, belum termasuk relawan SA Grogol yang juga mengikuti kegiatan. Kegiatan dilaksanakan pada hari Minggu tanggal 17 November 2019 di Rumah Karya Sahabat Anak Grogol. Rangkaian kegiatan dilaksanakan dengan urutan sebagai berikut:

1. Tim PKM datang ke tempat kegiatan pelaksanaan dan menyiapkan segala hal yang diperlukan selama kegiatan (meja registrasi dan peralatan untuk penyuluhan).

2. Anak-anak Sahabat Anak yang minimal berusia 4 tahun yang telah selesai maupun tidak ikut bimbingan belajar mendaftarkan diri di meja pendaftaran.

3. Setelah seluruh peserta terkumpul, maka acara akan dibuka dengan sambutan dari ketua Sahabat Anak Grogol dan ketua tim PKM untuk menjelaskan maksud atau tujuan dari kegiatan.

4. Setelah itu, oleh mahasiswa/ tim PKM akan membagikan kuesioner dan pre-test kepada seluruh peserta penyuluhan untuk diisi dan dikembalikan.

5. Kemudian acara dilanjutkan dengan penyuluhan oleh pembicara dari dokter spesialis paru (Gambar 2).

6. Setelah penyuluhan selesai, akan dilanjutkan dengan sesi tanya jawab.

7. Mahasiswa/ tim PKM akan membagikan post-test kepada seluruh peserta penyuluhan untuk diisi dan dikembalikan

8. Acara penyuluhan ditutup dengan pembagian konsumsi dan goody bag untuk setiap peserta PKM.

9. Foto bersama tim pelaksana PKM dan mitra serta penyerahan poster kepada mitra (Gambar 34). 


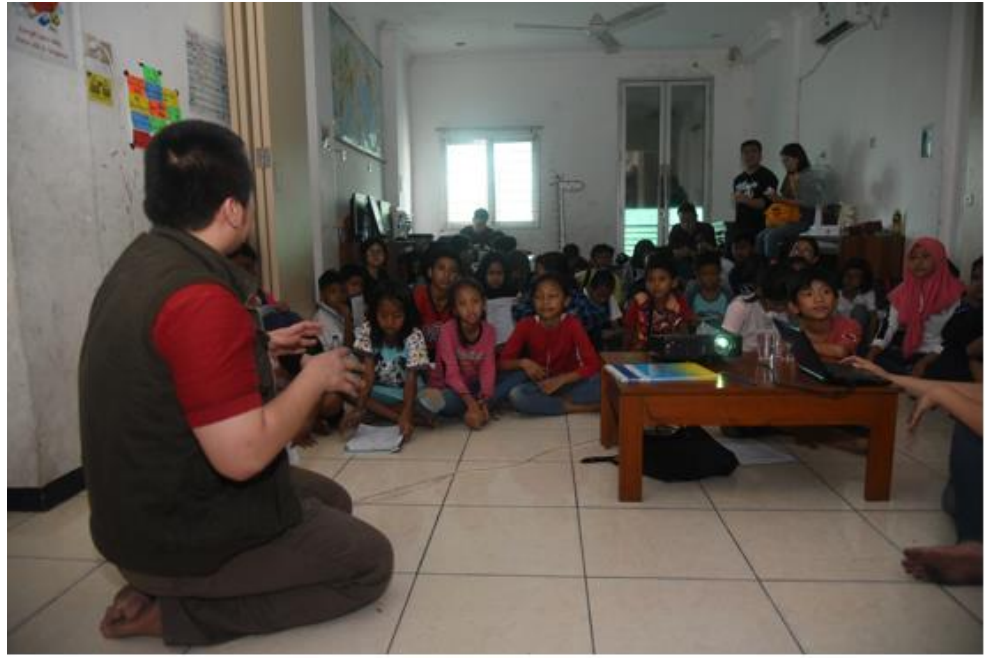

Gambar 2. dr. Hadisono, Sp.P sedang memberikan edukasi kepada peserta.

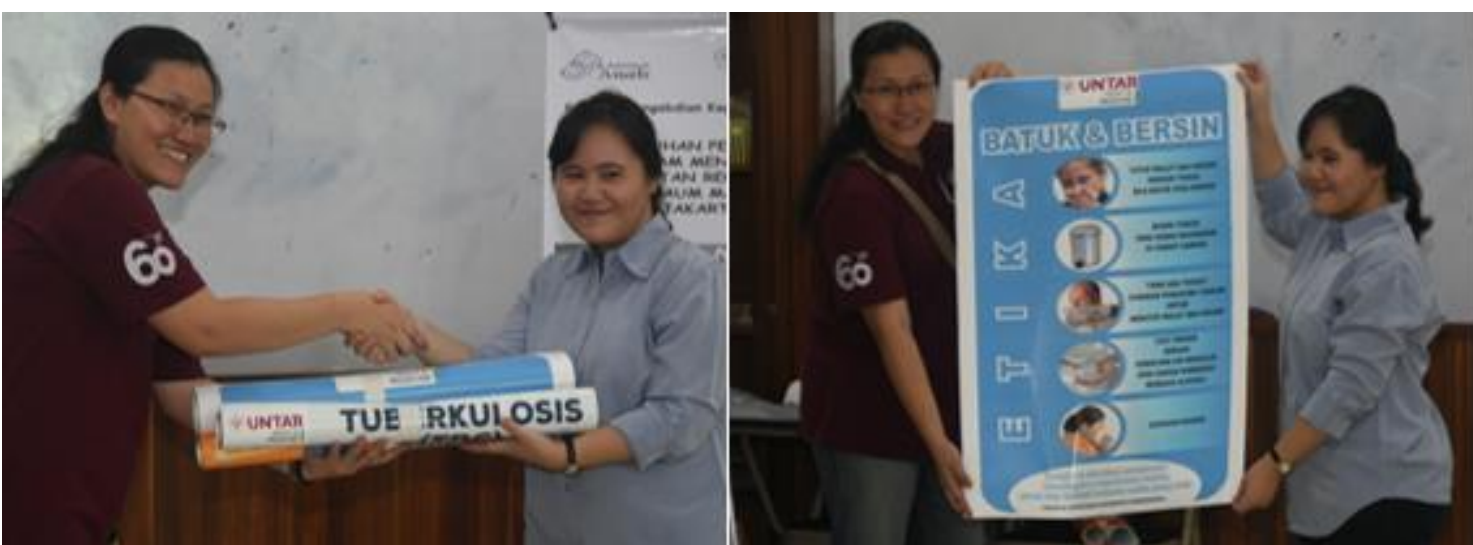

Gambar 3. Penyerahan poster kepada seluruh komunitas SA (9 wilayah) dengan masing-masing wilayah menerima 3 buah poster.

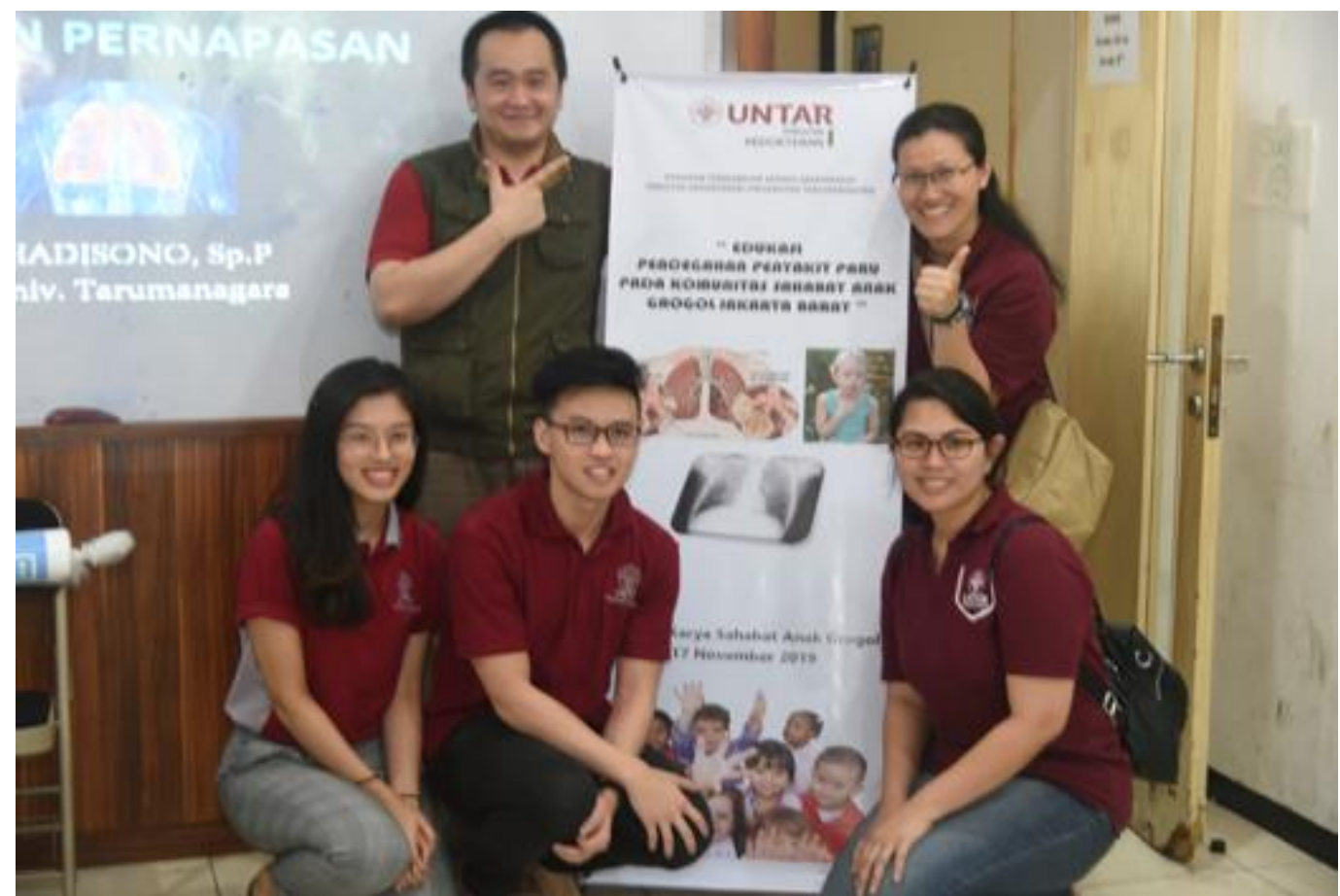

Gambar 4. Foto bersama tim pelaksana PKM 
Usia terkecil peserta adalah 4 tahun dan terbesar 19 tahun. Kuesioner, pre-test dan post-test hanya dikerjakan oleh 77 peserta, dari kelas 4 SD ke atas dengan rentang umur 10-19 tahun. Hasil kuesioner didapatkan 11 (14\%) anak merupakan anak yang >8 jam perhari bekerja di jalan, sisanya 66 anak merupkan anak marjinal yang tidak bekerja di jalanan. Semua peserta tidak merokok, tetapi $50(64,94 \%)$ anak tinggal dan hidup di keluarga, teman atau lingkungan perokok. Hasil ini dapat memperberat prevalensi COPD di Indonesia dan dapat disimpulkan polutan di jalanan merupakan risiko terbesar terjadinya penyakit saluran pernapasan terutama COPD pada anak jalanan. Hasil pre-test dan post-test untuk mengetahui tingkat pengetahuan didapatkan rerata peningkatan pengetahuan dari benar 2 jawaban dari 7 soal $(28,57 \%)$ menjadi benar 5 jawaban dari 7 soal $(71,43 \%)$. Hasil ini diharapkan dapat mengurangi risiko angka kejadian penyakit saluran pernapasan pada anak-anak binaan Sahabat Anak Grogol.

\section{KESIMPULAN DAN SARAN}

Kegiatan PKM seperti ini perlu dilaksanakan untuk menambah pengetahuan anak-anak yang sering atau selalu berada di jalan untuk bekerja mengenai gejala-gejala, bahaya dan pencegahan penyakit paru dan saluran napas serta merubah perilaku mereka untuk pencegahan dan penularan penyakit. Selain itu, peningkatan pemahaman dan pengetahuan dapat menurunkan angka kejadian penyakit paru dan saluran napas tidak menular serta tidak menular di Komunitas Sahabat Anak dan akhirnya meningkatkan kualitas hidup mereka. Edukasi mengenai cara saat batuk dan bersin yang benar juga dapat mengurangi risiko penularan penyakit. Hasil skrining menunjukkan bahwa polutan di jalan (asap kendaraan, debu, asap rokok, dan lain-lain) menjadi faktor risiko terjadinya PPOK. Peningkatan rerata tingkat pengetahuan dari hasil pre-test dan post-test diharapkan mengurangi risiko angka kejadian penyakit saluran pernapasan pada anak-anak binaan Sahabat Anak Grogol.

Berdasarkan kegiatan yang telah diselenggarakan dan feedback dari Sahabat Anak Grogol, dapat disarankan:

1. Materi kegiatan lebih dalam dan detail untuk anak yang lebih dewasa, waktu pelaksanaan agak diperpanjang sehingga peserta dapat memahami lebih baik.

2. Dapat dikembangkan untuk penelitian berbasis pengabdian.

3. Menindaklanjuti hasil laporan kegiatan PKM sehingga dapat melakukan kegiatan pengabdian berkelanjutan serta membuat rancangan strategi PKM selanjutnya.

4. Dosen Fakultas Kedokteran dari semua multidisiplin ilmu dapat ikut lebih aktif melaksanakan kegiatan pengabdian kepada masyarakat.

Ucapan Terima Kasih (Acknowledgement)

Terima kasih kepada DPPM Universitas Tarumanagara, Komunitas Sahabat Anak Grogol beserta relawan yang telah banyak membantu dalam menyediakan perizinan, sarana dan prasarana yang dibutuhkan dalam pelaksanaan kegiatan PKM.

\section{REFERENSI}

CDC. (2018). What Are the Risk Factors for Lung Cancer?. Available from: https://www.cdc.gov/cancer/lung/basic_info/risk_factors.htm

European Respiratory Society. (2013). Respiratory diseases in the world: Realities of Today, Opportunities for Tomorrow. Available from: https://www.ersnet.org/pdf/publications/firsworld-report.pdf

Institute for Health Metrics and Evaluation (IHME). (2018). Findings from the Global Burden of Disease Study 2017. Available 
from:http://www.healthdata.org/sites/default/files/files/policy_report/2019/GBD_2017_Bo oklet.pdf

IQAir. (2019). Air quality and pollution city ranking. Available from: https://www.airvisual.com/world-air-quality-ranking

Kemenkes RI. (2019a). Data dan Informasi Profil Kesehatan Indonesia 2018. Diakses dari: http://www.depkes.go.id/resources/download/pusdatin/profil-kesehatan-indonesia/Datadan-Informasi_Profil-Kesehatan-Indonesia-2018.pdf

Kemenkes RI. (2019b). Hasil Utama Riskesdas 2018. Diakses dari: http://www.depkes.go.id/resources/download/infoterkini/materi_rakorpop_2018/Hasil\%20Riskesdas\%202018.pdf

Mayo Clinic. (2017). COPD. Available from: https://www.mayoclinic.org/diseasesconditions/copd/symptoms-causes/syc-20353679

Quaderi, S.A., Hurst, J.R. (2018). The unmet global burden of COPD. Glob Health Epidemiol Genom., 3(4). Available from: https://www.ncbi.nlm.nih.gov/pmc/articles/PMC5921960/pdf/S2054420018000015a.pdf

Robinson, J. (2018). Lung disease overview. Available from: https://www.webmd.com/lung/lungdiseases-overview\#1

Sahabat Anak. (n.d.). Diakses dari: https://sahabatanak.org/

Terzikhan, N., Verhamme, K.M., Hofman, A., Stricker, B.H., Brusselle, G.G., Lahousse, L. (2016). Prevalence and incidence of COPD in smokers and non-smokers: the Rotterdam Study. Eur J Epidemiol., 31(8):785-792.

WHO. (2007). Global surveillance, prevention and control of Chronic Respiratory Diseases: A comprehensive approach. Available from: https://www.who.int/gard/publications/GARD\%20Book\%202007.pdf

WHO. (2018). Global Tuberculosis Report 2018. Available from: https://www.who.int/tb/publications/global_report/en/

Yustikarini,K., Sidhartani, M. (2015). Faktor Risiko Sakit Tuberkulosis pada Anak yang Terinfeksi Mycobacterium Tuberculosis.Sari Pediatri, 7(2), 136-140. 